\title{
Teaching Vocabulary Using Modified Snakes and Ladders Game
}

\author{
Imam Setiawan ${ }^{1}$, Muhammad Mujtaba Mitra Zuana ${ }^{2}$ \\ ${ }^{1}$ Institut Teknologi Adhi Tama Surabaya, ${ }^{2}$ Institut Pesantren KH. \\ Abdul Chalim \\ (1imamsetiawan327@gmail.com, ${ }^{2}$ mujtaba.mitrazuana@gmail.com)
}

\section{Key Words: \\ Modifying \\ Electronic Snakes and \\ Ladders game}

Second graders

\section{Kata Kunci: \\ Modifikasi \\ Game Elektronik Ular Tangga}

Siswa kelas dua

\section{ABSTRACT}

Many teachers fail to create a creative learning activity based on the children's characteristics. In fact, many of today's elementary schools are equipped with modern technology facilities that can encourage the children's motivation in vocabulary learning. Unfortunately, the facilities are still used monotonously in learning activity. This invariable learning activity may cause boredom for young learners. One of the ways to solve the problem is by developing a suitable teaching aid to increase vocabulary learning quality for young learners; it is the electronic Snakes and Ladders game. Therefore, this study aims to develop the conventional format of Snakes and Ladders game into electronic format for the teaching of English vocabulary to the second graders and to investigate the students' responses toward the game developed. The results in revision I and revision II shows that there are some revisions made dealing with the features and content during the development of the game. While the content is revised by adding more questions amount and variation. Overall the material used and the features exposed in electronic Snakes and Ladders game are appropriate with the second graders characteristics and learning objective. Furthermore, the students show positive response toward the electronic Snakes and Ladders game.

\section{ABSTRAK}

Banyak guru gagal menciptakan kegiatan belajar kreatif berdasarkan karakteristik anak-anak. Faktanya, banyak sekolah dasar hari ini dilengkapi dengan fasilitas teknologi modern yang dapat mendorong motivasi anak-anak dalam pembelajaran kosakata. Sayangnya, fasilitas tersebut masih digunakan secara monoton dalam kegiatan pembelajaran. Kegiatan belajar yang tidak berubah ini dapat menyebabkan kebosanan bagi pelajar muda. Di antara solusi tersebut adalah dengan mengembangkan alat peraga yang sesuai untuk meningkatkan kualitas pembelajaran kosa kata dengan permainan Ular Tangga elektronik. Oleh karena itu, penelitian ini bertujuan untuk mengembangkan format permainan Ular Tangga konvensional dalam format elektronik untuk pengajaran kosakata B. Inggris ke siswa kelas dua dan untuk mengetahui respon siswa terhadap permainan yang dikembangkan. Ada beberapa revisi yang dilakukan berkaitan dengan fitur dan konten selama pengembangan game. Revisi tersebut dengan menambahkan lebih banyak jumlah pertanyaan dan variasi. Secara keseluruhan bahan yang digunakan dan fitur yang diekspos dalam permainan Ular Tangga elektronik sesuai dengan karakteristik siswa dan tujuan pembelajaran. Selanjutnya, para siswa menunjukkan respon positif terhadap permainan tersebut.

Imam Setiawan, Muhammad Mujtaba Mitra Zuana

Teaching Vocabulary Using Modified Snakes ALSUNA Vol. 1 (2), 2018 and Ladders Game 


\section{Introduction}

Nowadays, the teaching of English starts from the early ages of children. At this beginning level, the teaching of vocabulary is important because it is the biggest component in mastering a language(McCarthy). Unfortunately, many teachers fail to make the vocabulary items they have taught retain in children's long-term memory (Pinkley, no date: 1). It is because they are not able to create an appealing teaching activity based on the characteristics of young learners. Besides, they cannot make use of the available school facilities. In reality, many of today's school are equipped with modern technology facilities. Even though technology can be used in teaching activities, it is still used monotonously. These invariable learning activities may cause boredom for young learners. Therefore, there is a need to enhance vocabulary learning quality using appropriate teaching activity for young learners.

"Learning vocabulary is an ongoing process that takes time and practice" (Mehring) Thus, learning vocabulary is not only about knowing new words and spending time memorizing. It is also about how to store the words in long-term memory in a creative way. Moreover, vocabulary is not easy to be taught especially to young learners who have tendencies to be very active in class. A teacher should know the children's characteristics in order that a convenient learning process of vocabulary can be conducted. The characteristics of most young learners is described well by (Scott, W. A. and Ytreberg) who state that young learners are keen on playing and they learn best when they are enjoying themselves. Somehow, they have a good ability to absorb language through playing and others activity which they find enjoyable.

However, it is not enough to understand the characteristics of young learners only. A teacher should also know the other factor that can support the success of teaching vocabulary to them. In fact, the use of technology as supporting media in learning process is becoming a trend recently. It is due to the increasing modernity of technology. Technology is now believed as a new revolutionary way in teaching activities. In line with that, (Abdelraheem, A. Y., \& AlRabane) suggest that technology has a big potential to be a tool that can overcome the traditional setting of the classroom which is isolated, supply access to rich resources and increase overall productivity. 
Furthermore, children in today's society are already in touch with technology in the form of electronic media such as computer. They spend time with electronic entertainment as much time as they normally play outside(Wartella, E. \& Richert). Many children are now playing games in computer since the electronic games are usually engaging. They contain many exciting features that can be explored. Also, a game created in electronic format may not be a novelty for the children as long as it is familiar to them. A familiar game for children will automatically excite them. In that way, the children can enjoy the lesson very much and their motivation in learning can arise.

From the explanation above, it is clear that the use of computer technology is very potential for language learning because it can perform multiple tasks for teaching activity(AlSeghayer). Of course it will be better to present the computer technology in the form of game since game can create more meaningful context for language learning(Wright, A., Betteridge, D., \& Buckby). Therefore, both of the aspects can support one another. Related to the use of games, there are many familiar games that can be used to gain the students' motivation such as word game, puzzle, hangman, crossword puzzle, Simon says, miming game, and Snakes and Ladders game. Snakes and Ladders game can be suggested as a way to teach vocabulary.

Snakes and Ladders is a traditional game. Many people have been familiar with this classic game including children. It is played by two or more people using dices and potsies on a playing board. The board is divided into numbered squares and has a number of snakes and ladders on it which connect one square to another up and down. The rules are easy to be done so that children will not find difficulties in playing the game. Unfortunately, the use of this game in language teaching is still found in conventional format. Many teachers who want to use this game as a teaching tool give a little modification from the old format. Therefore, it is necessary to develop the game into electronic version in order to make it much more fascinating. The modification made in the electronic format is needed to provide appropriate teaching aid for children. By doing so, electronic Snakes and Ladders game can motivate the students in learning new vocabulary because of its attractive appearance and sophisticated form. The content can improve not only children's vocabulary size but also vocabulary comprehension due to the 
picture existence. In addition, the children can learn individually or cooperatively since the games is designed interactively.

Hence, this research is conducted to investigate whether playing and learning vocabulary through "Snakes and Ladders" game in the form of computer game is helpful in motivating the children to improve their vocabulary size. The researcher intends to develop Snakes and Ladders game in the form of computer game at elementary school level especially for the second graders.

From the background of the study above, it is acknowledged that there is a necessity to develop the conventional format of Snakes and Ladders game into electronic format for the teaching of English vocabulary to the second graders. Related to that, there is also a need to investigate the students' responses toward the game developed.

\section{Method}

This research uses Research and Development method ( $\&$ D) as the research type since it aims to develop a new product as a medium to teach English (Cohen, L., Manion, L., \& Morrison). According to (Borg, W. R. and Gall), there are several steps used in the R \& D cycle to develop a new product. In this study, all the procedures suggested by Borg and Gall were not fully undertaken by the researcher. Some parts are omitted instead. It was done since the researcher intends to develop a new educational product and to investigate students' responses toward the product, not to examine the effectiveness of the product on students' academic achievement. The procedures used by the researcher are described in these steps: 


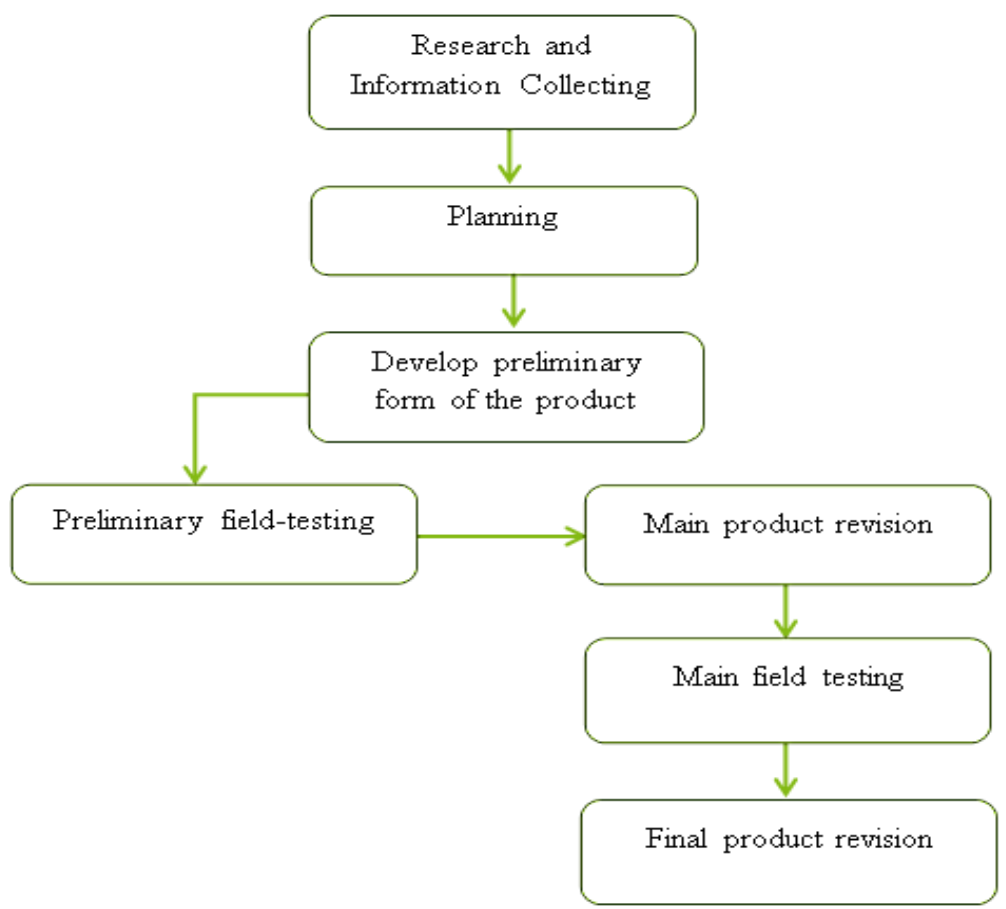

Figure 1. Product development procedure used by the researcher

Descriptive technique was used to analyze the data in this study. The data obtained was analyzed based on the data collection technique order. Firstly, the data collected from questionnaires were read and studied carefully. Secondly, the data were analyzed in order to prepare the new product before being tested. Thirdly, the data gained from observations and interview guidelines were also read and studied carefully. Fourthly, the inappropriate data were eliminated. Fifthly, the data were described and arranged based on the date. The last, the data were analyzed based on the interpretation of the researcher. All data from observation, questionnaire, and interview guidelines were presented in the form of word.

\section{Product Design Planning}

Based on the needs analysis done by the researcher as in the first research procedure, research and information collecting, there were some considerations.

The first was analysis of learning context. It was known that the school, in this case the school has good facilities that can support the learning process such as computer and LCD in each classroom and multimedia room. The teacher usually makes use computer and LCD only to display presentation slide in order to explain new materials to the learners. She utilizes games 
including Snakes and Ladders as well. Unfortunately, the game used is still in conventional format whereas it can be presented in electronic format with the support of the facilities existed.

The next was analysis of learner's characteristics. From the discussion and unstructured interview with the classroom teacher, the researcher found that most students are visual learners. They are used to the use of presentation slide utilized by the teacher when explaining new materials. It is because they are more receptive to something that is presented visually rather than in auditory. In addition, most of them also have equipped with good facility in learning at home, say, computer. Therefore, they are used to playing computer game at home. Moreover, the student's mastery of common vocabulary is quite well since the teacher usually combines the use of English and Indonesian as instructional language in the classroom. Nevertheless, some students in the classroom still find difficulty in understanding new vocabulary

The last was task analysis. Through documentation data, a syllabus consists of competency standard and basic standard that should be mastered by the learners was obtained. This syllabus is in the form of unit plan which is allocated in 8 weeks. From the results of the needs analysis above, the researcher arranged a learning strategy using electronic Snakes and Ladders game as a classroom activity. This game aims to strengthen and evaluate the learner's understanding after being introduced to new vocabulary by focusing on visual exposure.

\section{Implementation}

This study intends to develop the conventional format of Snakes and Ladders game into electronic format and to investigate the students' responses toward the game. During the game development, there are two kinds of revision done by the researcher in the process of developing the electronic Snakes and Ladders game. In the first revision, the changes are focus on the game features such as color and text. The color is sharpened and the text is set a little bit bigger. Besides, an "answer" button is also attached in the board in order to check the correct answer. While the second revision focuses on the content of the game in the form of questions. There are several repetitions of question happened during the field-testing and it reduces challenge in playing the game. This problem is resolved by adding more questions input from 
24 questions into 34 questions. In that way, the possibility of repeating the same questions can be minimized.

Based on the development made by the researcher, this electronic game has fulfilled four of five multimedia elements stated by (Asthana). The first element is text. In this game, text is not only used to deliver the questions (material) but also to show instruction. For instance, "push" button requires the player to push it in order to move the potsie. Therefore, the students are able to learn instructional words. The next element is animation. Animation in this game is represented by the potsie. The potsie can move or jump by itself when the number in "push" button is appeared. The third element is graphics. Graphics in this game is presented in the form of picture and color. Picture and color are not only helpful in adding excitement of the game but also in understanding the material better. The last element is sound. The sound is appeared automatically when the "Answer" button is clicked. It shows how to say the words or sentences correctly. In this manner, the students are able to imitate the correct pronunciation of the English words as well. This functions as additional knowledge for students.

Related to the game elements, it is discovered that the colors used in the game board are quite interesting for the second graders and the colors do not decrease the font clarity. The pictures existence in the game fascinates the students especially the cartoon characters such as Spongebob, Patrick, Squidward, and Mr.Krab. Those characters are the player's potsies. They add excitement since they are moveable automatically. In addition, the pictures do not interrupt the text and do not distract the students' concentration. The text used in the game is clear and readable. It is able to be read clearly even if when it is seen from the distance. On average, all the features in the game interest the students.

Viewed from the content of the game, it is found that the material used in the game is suitable with the material and the learning objectives of the second graders. Although a few students might find the questions are difficult, still they enjoy the game. Overall, most students are able to answer the questions in the game. It shows that the difficulty level of the questions is not too high for the students. Besides, the language used to deliver material in the game is very clear and concise. As a result, it is easy to understand even though the types of questions used are varied. 
Students' responses toward the game are positive. It can be seen from the result of fieldtesting I and field- testing II. The amusement and the disappointment atmosphere when playing game are real in the second-field testing since the players get "Snake" and "Ladder". Most students are interested with the cartoon characters, it is Spongebob and friends. Indeed, Spongebob series on TV has become children's favorite. Thus, they can easily get involved in the game since they find something they like.

This fact is in line with (Thouvenelle, S. \& Bewick) that children in their early years are very sensitive and they can absorb what they see and hear through multisensory experiences. In electronic Snakes and Ladders, they can find visual exposures in the form of cartoon characters they have seen before. When they find it again visualized in computer game, they are easily attracted. As the impact, the exposures offered by electronic Snakes and Ladders do not only affect what they think but also how they feel about themselves. If they are impressed with the game then it will be much easier for them to think and receive what is there in the game.

\section{Conclusion}

Before conducting this research, a needs analysis through observation in the school was held. Based on needs analysis the result, it is acknowledged that the school has equipped with good facilities such as computer and LCD. The teacher usually makes use of computer and LCD only to display presentation slides in explaining new materials to the learners since most of them are visual learners. Games such as Snakes and Ladders are also used but it is still in conventional format. As a matter of fact, the games can be presented in electronic format with the support of the facilities existed. Therefore, there is a necessity to convert the conventional game, in this case Snakes and Ladders game, into electronic format in order to engage the learners in the learning process.

In developing electronic Snakes and Ladders, there are several steps that should be done: administering small scale feasibility testing, field-testing, and revising the product. The small scale feasibility testing involves material and media expert. From the small survey, it is known that the product developed is appropriate with the students learning objective and ability. During the field-testing, the students show positive responses toward the game as they enjoy 
playing the game. Revisions are made related to the color and font appearance, addition of "answer" button, addition of voice in the answer box, and the prevention of question repetition.

Through all processes held by the researcher, it can be concluded that this research and development has created an electronic Snakes and Ladders game which is designed suitably with the needs of the second graders of the school as a learning medium for teaching vocabulary. This electronic game also fulfills four of three elements of multimedia for learning, they are text, animation, graphics, and sound.

\section{Bibliography}

Abdelraheem, A. Y., \& Al-Rabane, A. H. "Utilisation and Benefits of Instructional Media in Teaching Social Studies Courses as Perceived by Omani Students." Malaysian Online Journal of Instructional Technology, vol. 2, 2015, pp. 1-5.

Al-Seghayer, K. "The Effect of Multimedia Annotation Modes on L2 Vocabulary Acquisition: A Comparative Study.” Language Learning and Technology, vol. 5, no. 2, 2001, pp. 202-32.

Asthana, A. Multimedia in http://encyclopedia.jrank.org/articles/pages/6821/Multimedia-in Education.html\#ixzz1fjLxopUR.

Borg, W. R. and Gall, M. D. Educational Research: An Introduction. USA: Longman Inc. 1983.

Cohen, L., Manion, L., \& Morrison, K. Research Methods in Education 5th Edition. Great Britain. RoutledgeFalmer, 2005.

McCarthy, M. Vocabulary. Oxford University Press, 1990.

Mehring, J. G. Developing Vocabulary in Second Language Acquisition: From Theories to the Classroom. 2005.

Pribadi, Benny A. Model Desain Sistem Pembelajaran. Dian Rakyat, 2010.

Scott, W. A. and Ytreberg, L. H. Teaching English to Children. Longman, 1990.

Thouvenelle, S. \& Bewick, C. J. Completing the Computer Puzzle: A Guide for Early Childhood Educators. Pearson education, 2003.

Wartella, E. \& Richert, R. A. Special Audience, Special Concerns: Children and Media. 2009.

Wright, A., Betteridge, D., \& Buckby, M. Games for Language Learning. Cambridge University Press, 1984. 